\title{
$12 q$
}

National Cancer Institute

\section{Source}

National Cancer Institute. 12q. NCI Thesaurus. Code C13533.

Distal (long) arm of chromosome 12 